\title{
$\mathrm{Cu}-\mathrm{Cr}-\mathrm{Zr}$ 合金の機械的特性に及ぼす酸化および水素添加の影響*
}

駒 崎 慎 一*1, 寺 由 忠 平*2
沓 澤 統 太*2, 森 谷 信 一*3

\section{Influences of Oxidation and Hydrogen-Charging on Mechanical Properties of $\mathrm{Cu}^{-} \mathrm{Cr}-\mathrm{Zr}$ Alloy}

\author{
Shin-ichi KOMAZAKI*4, Chuhei TERADA, \\ Tota KUTSUZAWA and Shin-ichi MORIYA \\ ${ }^{* 4}$ Graduate School of Engineering, Muroran Institute of Technology, \\ 27-1 Mizumoto-cho, Muroran-shi, Hokkaido, 050-8585 Japan
}

\begin{abstract}
$\mathrm{Cu}$ alloys used for recent rocket combustion chambers are exposed to severe conditions, i.e., high temperature environments with oxidizing followed by reducing. Therefore, it is very important to understand the effects of such severe environments on their mechanical properties for maintaining their integrity for a long time. In this study, in order to investigate the effect of internal oxidation on mechanical properties, $\mathrm{Cu}-\mathrm{Cr}-\mathrm{Zr}$ alloy was subjected to the oxidation test at $825^{\circ} \mathrm{C}$ for $15 \mathrm{~h}$ and then the small punch $(\mathrm{SP})$ test specimens $(\phi 3.0 \times 0.25 \mathrm{t}[\mathrm{mm}])$ were removed from the resultant internal oxidation layer. Some of SP specimens were exposed in the high temperature and high pressurized hydrogen gas atmosphere $\left(7.6 \mathrm{MPa}, 600^{\circ} \mathrm{C}, 24 \mathrm{~h}\right)$ for hydrogen-charging. The SP tests were applied to the oxidized and the hydrogen-charged specimens at the temperatures ranging from room temperature to $600^{\circ} \mathrm{C}$. Experimental results revealed that $\mathrm{Cr}$ and $\mathrm{Zr}$ were preferentially oxidized along grain boundaries and $\mathrm{Cr}$ precipitates were also selectively oxidized in the grains by the internal oxidation. The strength and ductility of oxidized specimen gradually decreased with increasing testing temperature accompanying intergranular brittle fracture, although the internal oxidation had almost no influence on the mechanical properties at room temperature. Additionally, the degradation of mechanical properties was more pronounced by the hydrogen-charging, especially, in room temperature.
\end{abstract}

Key Words: Nonferrous Metal, Cu Alloy, Hydrogen Embrittlement, Internal Oxidation, HighTemperature Strength, Brittle Fracture, Small Punch Test, Combustion Chamber

\section{1. 緒言}

H2-A口ふットなどに代表される液体ロケットエン ジンでは燃焼室の冷却のために再生冷却構造が採用さ れている(1). ロケットエンジン燃焼室とその断面を模 式的に示したものが図 1 である。Cu合金の冷却溝を 銅の電鋳層で覆い，その外側を $\mathrm{Ni}$ 基超合金(外筒)で 補強した構造となっており, 冷却溝を燃料である液体 水素が通ることによって燃焼器の冷却を行っている。 そのため, 燃焼室内筒には冷却効率の観点から熱伝導 性が高く，高温強度に優れた $\mathrm{Cu}$ 合金が用いられてい る.

一方，タフピッチ銅など酸素を含有する銅を還元性 の含水素がス中で加熱すると, 水素が銅中に拡散侵入 し, $\mathrm{Cu}_{2} \mathrm{O}$ を還元して水蒸気が発生する $\left(\mathrm{Cu}_{2} \mathrm{O}+\mathrm{H}_{2} \rightarrow\right.$

* 原稿受付 2009 年 12 月 22 日。

*1 正員, 室蘭工業大学大学院工学研究科(事050-8585 北海道 窒蘭市水元町 27-1)

*2 窒蘭工業大学大学院工学研究科.

*3 正員, (独) 宇宙航空研究開発機構(函 981-1525 角田市君荁字 小金沢 1).

E-mail : komazaki@mech.kagoshima-u.ac.jp $\left.2 \mathrm{Cu}+\mathrm{H}_{2} \mathrm{O}\right)$ ．水蒸気は高温高圧となり，ボイドを形 成し水素脆性を引き起こすことが知られている(2)。ま た，無酸素銅に打いても，高温酸化の後に高温還元雾 囲気中に曝されると，タフピッチ銅と同様に水素脆性 が生じると報告されている(3)、ロケットエンジン燃焼 器用 $\mathrm{Cu}$ 合金も当初は酸素を含有しないが，燃焼室内 では酸化剂および燃料である酸素および水素が局所的 に過濃となっている可能性があるため，そのような雾

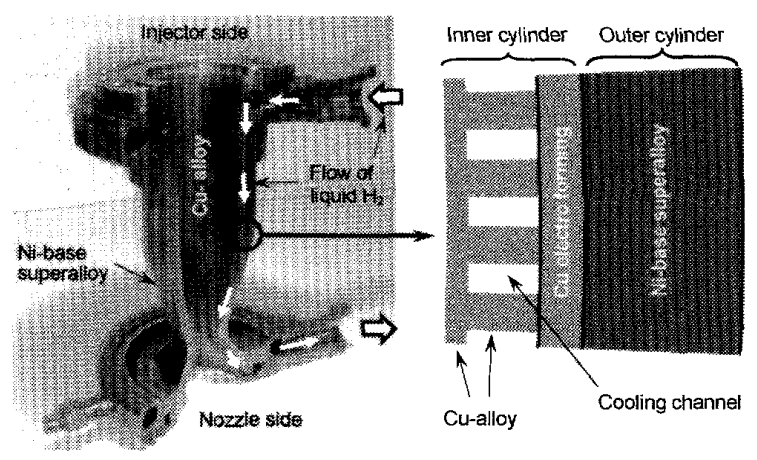

Fig. 1 Rocket combustion chamber and its cross section 
囲気にCu合金が繰り返し曝されるとエンジンの構造 健全性に重要な影響を及汸す可能性がある、スペース シャトルメインエンジンの然焼器の損傷においても, 酸化・還元の影響が指摘されている(4)。そのため，再 使用型ロケットエンジンの開発・運用飞扔いては, 燃 焼器用 $\mathrm{Cu}$ 合金に対する酸化・還元の影響についての 知見が不可欠であるといえる。

本研究では，燃焼器用 $\mathrm{Cu}-\mathrm{Cr}-\mathrm{Zr}$ 合金に関する基礎 的知見を得ることを目的とし，その機械的特性に及ほ す内部酸化および水素チャージの影響を調査した。冷 却溝の板厚は $1 \mathrm{~mm}$ 以下と極好薄く通常の大型試 験片を用いた標準試験法を適用できないため, TEM ディスク形状の徴小試験片を用いたスモールパンチ (SP：Small Punch) 試験により機械的特性を計測・ 評価した。

\section{2. 供試材および実験方法}

$2 \cdot 1$ 供試材 供試材として, 市販の $\mathrm{Cu}-\mathrm{Cr}-\mathrm{Zr}$ 合金 $(\mathrm{Cr}: 0.54$ mass\%, Zr : 0.09 mass\%, Fe : 0.01 mass $\%, \mathrm{~S}: 0.0007$ mass $\%$, Cu: Bal.) 用いた。 $945^{\circ} \mathrm{C} \times 15 \mathrm{~h}$ の溶体化処理の後に $475^{\circ} \mathrm{C} \times 5 \mathrm{~h}$ の時効処 理を施し，後述する試験に供した。以降，この時効処 理後の試料を受入れまま材(R材) と呼ぶこととした。 $\mathrm{Cu}-\mathrm{Cr}-\mathrm{Zr}$ 合金では時効処理により $\mathrm{Cr} \mathrm{Zr}$ の金属間 化合物が析出し，それらの相互作用により $\mathrm{Cu}-\mathrm{Zr}$ 合 金や $\mathrm{Cu}-\mathrm{Cr}$ 合金よりも優れた強度を実現してい る(5).

$2 \cdot 2$ 内部酸化処理 燃焼室壁が高温酸化雾国気 に曝された場合を想定して, 厚さ $0.6 \mathrm{~mm}$ の $\mathrm{R}$ 材を 用い, $825^{\circ} \mathrm{C}$, 大気中にて $15 \mathrm{~h}$ の条件で酸化試験を行 った。温度と時間については，あらかじめ実施した予 備実験の結果に基つうき, 表面酸化スケール(酸化銅)下
の試料内部がすべて内部酸化 ( $\mathrm{Cr}$ と $\mathrm{Zr}$ が選択的に酸 化），後述するスモールパンチ試験片が十分採取で きるような条件を選定した。また，王力については， 試験装置の制約上，今回忟大気圧とした。この内部酸 化した部分を内部酸化材 $(O$ 材) とした。他の試料も含 め，本研究で用いた試料とそれらの処理条件をまとめ て表 1 に示す。

$2 \cdot 3$ 水素化処理 内部酸化処理に供した試料 $(0$ 材）を用いて，600 $\mathrm{C}, 7.6 \mathrm{MPa}$ の高温高压水素ガス環 境中にて $24 \mathrm{~h} の$ 暴露試験を実施し，水素を $\mathrm{O}$ 材中に チャージした。温度については，ロケット燃焼器の壁 温度程度の温度とし，圧力は同じくロケット燃焼器の 燃焼圧 $(10 \mathrm{MPa})$ に対してできるだけ近づけるよう処 理装置の上限とした。また，処理時間については，材 料内部に十分水素が拡散するよう $24 \mathrm{~h}$ とた。この 試料を酸化後水素化材 $(\mathrm{OH}$ 材)とした。比較のため, 受入れまま材に対し同条件にて水素チャージを行った 試料も併せて作製した。な挔，本条件にて合金中に水 素が吸蔵されることを昇温脱離分析によりあらかじめ 確認している。

$2 \cdot 4$ 加熱時効処理 内部酸化処理および水素化 処理には高温での加熱が伴うので，内部酸化抢よび水 素チャージに伴う強度特性の変化には雲囲気の影響の みならず加熱時効(軟化)の影響も加算される。そのた め，内部酸化処理 $\left(825^{\circ} \mathrm{C} \times 15 \mathrm{~h}\right)$ および内部酸化処理 とその後の水素化処理 $\left(825^{\circ} \mathrm{C} \times 15 \mathrm{~h}+600^{\circ} \mathrm{C} \times 24 \mathrm{~h}\right)$ に 相当する熱履歷のみを与えた試料も準備し，それぞれ 酸化時効材 (OA 材) および酸化後水素化時効材 (OHA 材)とした。

$2 \cdot 5 \mathrm{SP}$ 試験 受入れまま材 $(\mathrm{R}$ 材)，内部酸化材 $(\mathrm{O}$ 材), 酸化後水素化材 $(\mathrm{OH}$ 材), 酸化時効材 $(\mathrm{OA}$ 材), 酸化後水素化時効材 (OHA 材) の各試料上り

Table 1 List of samples used in this study

\begin{tabular}{|c|c|}
\hline Samples & \multicolumn{1}{c|}{ Treatment conditions } \\
\hline $\mathrm{R}$ & $\begin{array}{l}\text { As-received } \\
\text { Solution-treatment: } 945^{\circ} \mathrm{C}, 15 \mathrm{~h}+\text { Aging: } 475^{\circ} \mathrm{C}, 5 \mathrm{~h}\end{array}$ \\
\hline $\mathrm{O}$ & $\begin{array}{l}\text { Internally oxidized } \\
\text { R sample } \rightarrow \text { Oxidation: } 825^{\circ} \mathrm{C}, \text { in air, } 15 \mathrm{~h}\end{array}$ \\
\hline $\mathrm{OH}$ & $\begin{array}{l}\text { Hydrogen-charged } \\
\text { O sample } \rightarrow \text { Hydrogen-charging: } 600^{\circ} \mathrm{C}, 7.6 \mathrm{MPa}, 24 \mathrm{~h}\end{array}$ \\
\hline $\mathrm{OA}$ & $\begin{array}{l}\text { Thermally aged } \\
\text { R sample } \rightarrow \text { Thermal aging: } 825^{\circ} \mathrm{C}, 15 \mathrm{~h} \text { (without oxidation) }\end{array}$ \\
\hline $\mathrm{OHA}$ & $\begin{array}{c}\text { Thermally aged } \\
\text { R sample } \rightarrow \text { Thermal aging: } 825^{\circ} \mathrm{C}, 15 \mathrm{~h}+600^{\circ} \mathrm{C}, 24 \mathrm{~h} \text { (without oxidation) }\end{array}$ \\
\hline
\end{tabular}


TEM ディスク形状の SP 試験片 $(\phi 3.0 \times 0.25 \mathrm{t}$

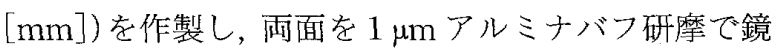
面まで仕上げた，SP 試験は，Ar ガス雾囲気中, 変位 速度: $0.2 \mathrm{~mm} / \mathrm{min}$, 温度条件: 室温 $600^{\circ} \mathrm{C}$ て実 施した. 試験後に破壊したSP 試験片の表面や破面に 加え, 内部酸化扔上び水素化処理材を切断した後の切 断面を, 走査型電子顕微鏡 $(\mathrm{SEM})$ や電子線マイクロ アナライザー(EPMA)を用い観察した。

\section{3. 結果および考察}

$3 \cdot 1$ 内部酸化および水素化による組織変化 内 部酸化処理を途中で止めた試料を切断した後の断面の 光学顕微鏡写真を, 図 2 に示寸.なお，試料表面に形 成された銅の酸化スケールは剥離してしまったため, 写真には写っていない. 表面近傍に試料内部(健全部) と様相の異なる変質層が認められる. 変質層の厚さは 酸化時間の増加とともに増した. 変質層の組織を EPMAの線分析により調查した結果, 図 3 に示すよ

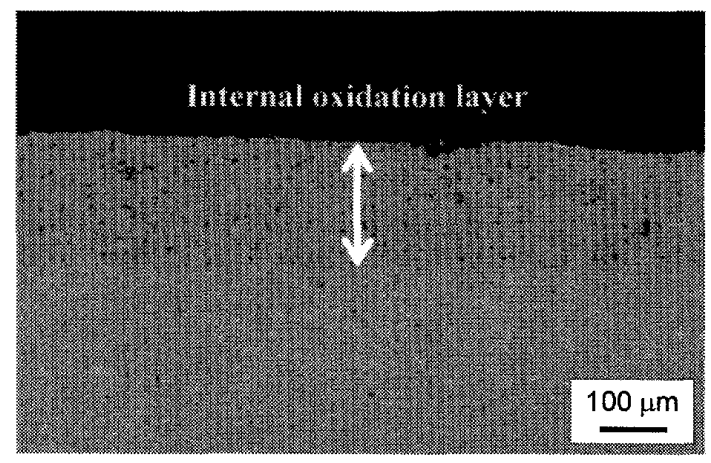

Fig. 2 Internal oxidation layer formed on $\mathrm{Cu}^{-} \mathrm{Cr}-\mathrm{Zr}$ alloy

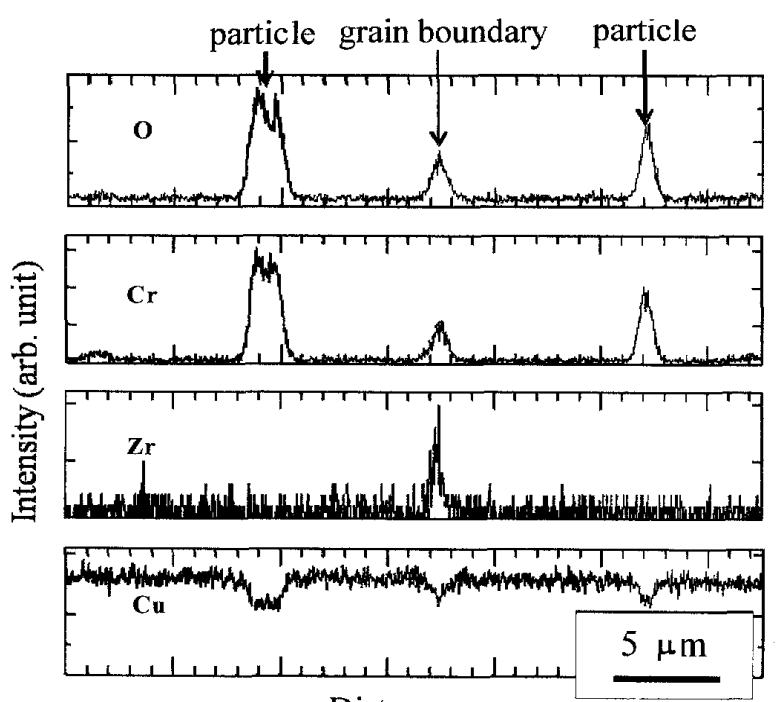

Distance

Fig. 3 EPMA results of internal oxidation layer
うに，粒界上では $\mathrm{Cr}$ と $\mathrm{r}$ が，粒内では数 $\mu \mathrm{m}$ 程度の Cr 粒子が優先的に酸化しておう，この層は内部酸化 層であることがわかった。なお，前述したように，こ の酸化処理を長時間 $(15 \mathrm{~h})$ 行い, 試料をすべて内部酸 化 ( $\mathrm{Cr}$ と $\mathrm{Zr}$ を選択的に酸化)させた試料が内部酸化材 (O材)である.

$\mathrm{O}$ 材に水素チャージした試料 $(\mathrm{OH}$ 材) のミクロ組織 を光学顕微鏡, SEM, EPMA 等を用いて調査したが, O材と大きな差異は認められなかった。また，タフピ ッチ銅などで報告されている酸化物の還元やその結果 形成されるボイド(2)などは今回観察されなかった。 なお，水素チャージ後の試料を水素昇温脱離分析に供 した結果, $600^{\circ} \mathrm{C}$ 近傍にピークを有する水素放出スぺ クトルが計測され，水素が合金中に吸蔵されているこ とを確認した。

$3 \cdot 2$ 内部酸化に伴う機械的特性の変化 $\mathrm{R}$ 材と $\mathrm{O}$ 材で測定された荷重一荷重線上変位曲線の例を, 図 4 に示す。R材での結果 [図 4(a)]をみてみると, 試 験温度が室温, $300^{\circ} \mathrm{C}, 500^{\circ} \mathrm{C}$ 上昇するにつれて最大 荷重 $\left(P_{\max }\right)$ が少しずつ低下している。しかし, 破断変 位 $\left(\delta_{f}\right)$ はあまり大きく変わらない。他方, $\mathrm{O}$ 材 [図 4(b)]については, 強度レベルは R 材に比べ全体的 に低く, 試験温度の上昇に伴う $P_{\max }$ の低下もより顕 著である。さらに，同図からわかるように， R 材とは 異なり $\delta_{f}$ も大きく減少している.

$\mathrm{SP}$ 試験後の両材の試験片外観とO 材の破面を

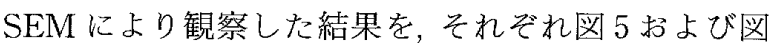
6 に示す， R 材の破壞は，試験温度に依存せず，ボ一 ルと試験片が接触し応力あるいはひずみが最大となる 円周上に沿って延性的に生じており，破面は粒内デく ンプルを呈していた。 O材については，室温における 破壊形態は $\mathrm{R}$ 材と同様マク口的には延性破壞であっ

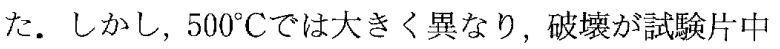
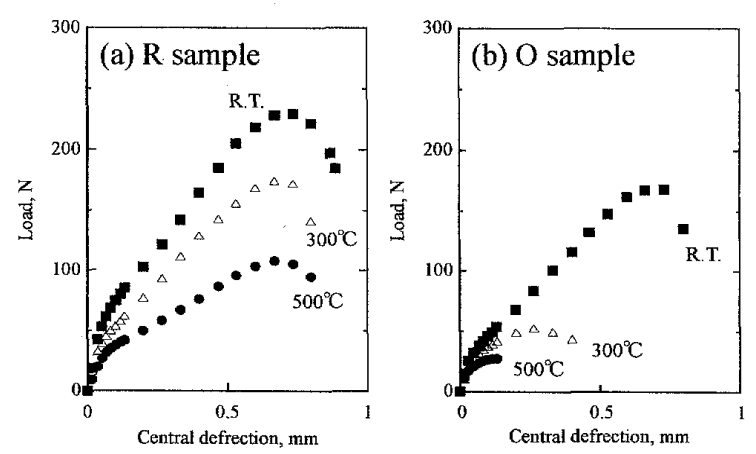

Fig. 4 Load $^{-}$central deflection curves measured on ( a ) $\mathrm{R}$ sample and ( b ) O sample at R.T., $300^{\circ} \mathrm{C}$ and $500^{\circ} \mathrm{C}$ 
心より放射線状に発生して招り，脆性材料の典型的な 特徴が観察された。図 6(b) からわかるように, 䆓温

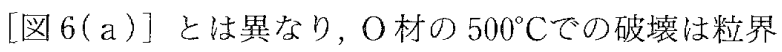
に沿って生じていたＳPP試験片を二分割した断面を EPMAにより観察した結果, 内部酸化している粒界 に沿ってき裂が進展していた。

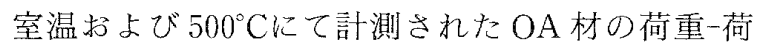

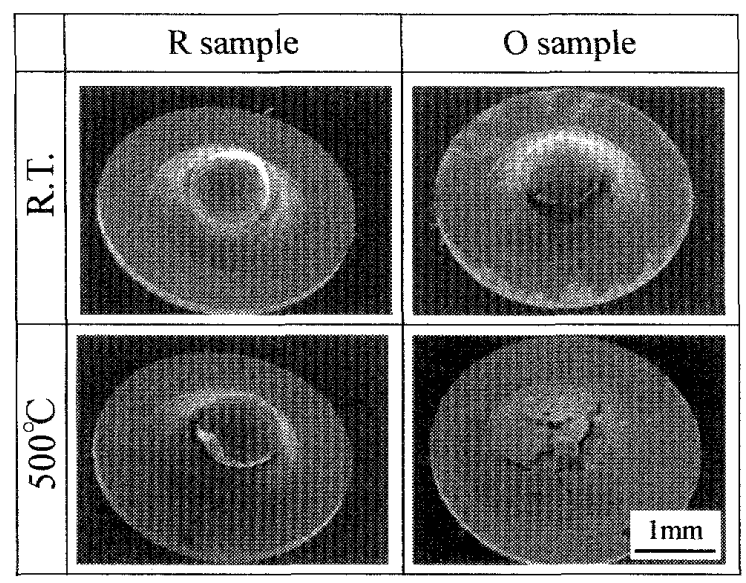

Fig. 5 SEM micrographs of fractured specimens of $\mathrm{R}$ and $\mathrm{O}$ samples tested at R.T. and $500^{\circ} \mathrm{C}$
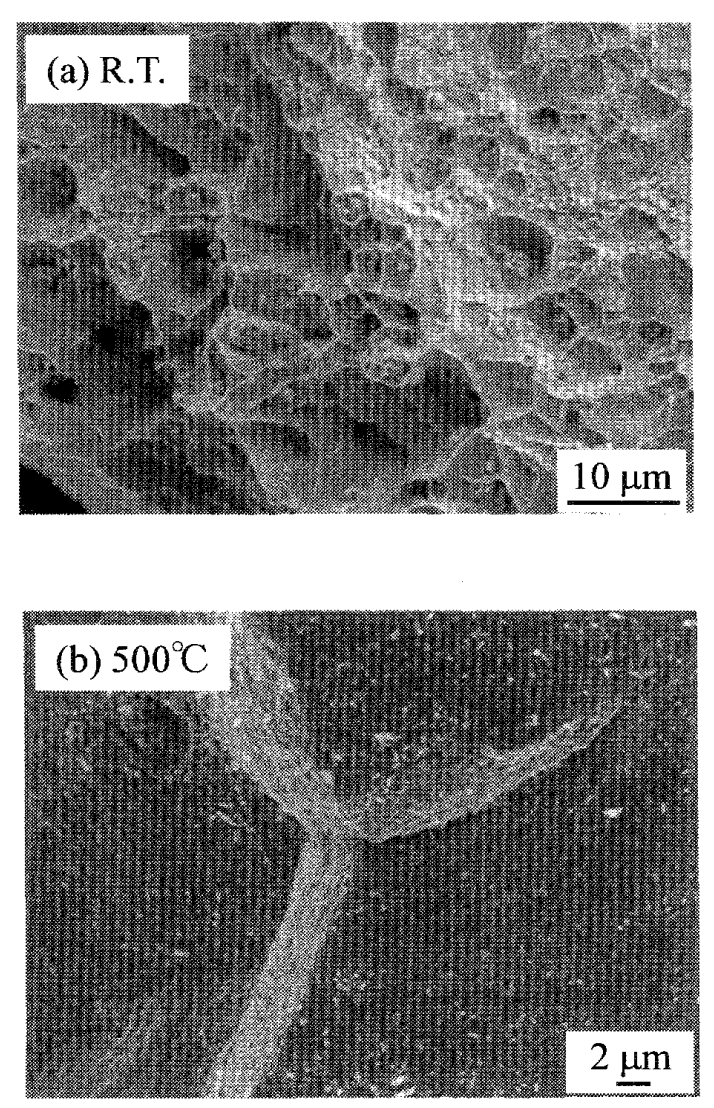

Fig. 6 SEM micrographs of fracture surfaces of $\mathrm{O}$ samples fractured at (a) R.T. and (b) $500^{\circ} \mathrm{C}$
重線上変位曲線を, $\mathrm{R}$ 材抢よび $\mathrm{O}$ 材のものと併せて図 7 に示す。室温においては，O材とOA材の $P_{\max }$ は ほほ同等で，OA材の $\delta_{f}$ がわずかに増加している。

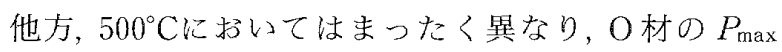
と $\delta_{f}$ が OA材のそれらに比べ大きく低下している。 こ机は, $\mathrm{O}$ 材の室温における強度低下の要因は内部酸 化層形成というよりはむしろ加熱時効による軟化であ り, 内部酸化愿の形成は $\mathrm{Cu}-\mathrm{Cr}-\mathrm{Zr}$ 合金の室温に打け る強度や破断延性にあまり影響を及沽さないことを示

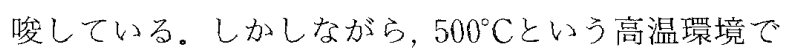
は異なり, 内部酸化層の形成そのものが高温での機械 的特性(強度と延性) 大きく劣化させることが明らか となった。

O材およびOA材の $P_{\max }$ と斿堂試験温度に対し てプロットしたものを, 図 8 に示す。O材のP $P_{\text {max }}$ 扮

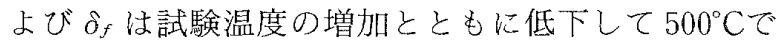

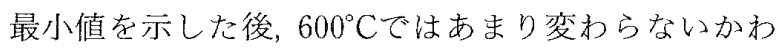
ずかに回復する傾向がある。一方，OA材についても， $P_{\max }$ は試験温度の増加とともに低下するが, その低下 量は $\mathrm{O}$ 材に比心゙大きくない. また，O材の $\delta_{f}$ に比べ
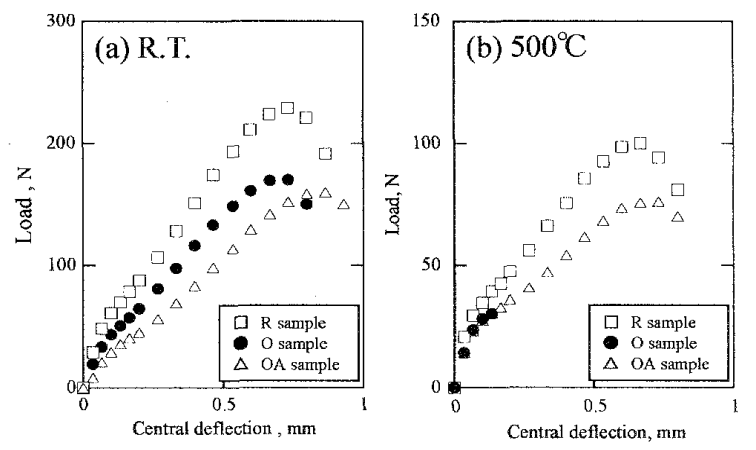

Fig. 7 Load-central deflection curves measured on $\mathrm{R}, \mathrm{O}$ and $\mathrm{OA}$ samples at (a) R.T. and (b) $500^{\circ} \mathrm{C}$

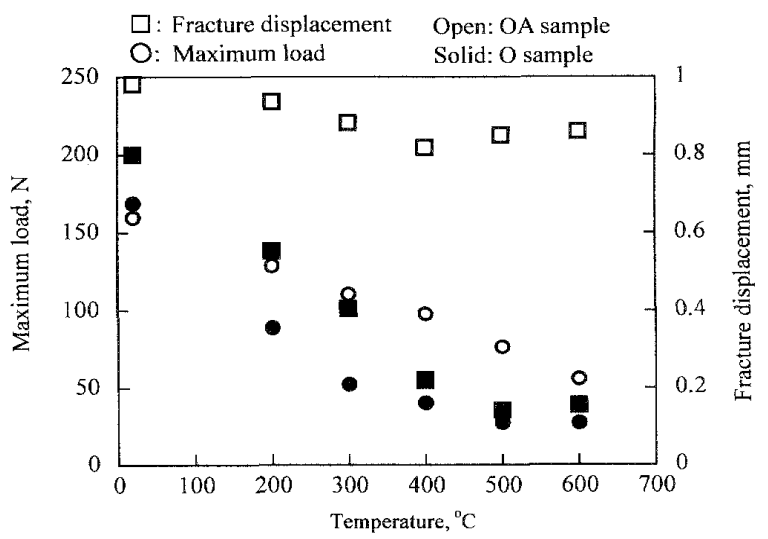

Fig. 8 Maximum load and fracture displacement plotted as a function of testing temperature 
その低下量はわずかではあるが, $\mathrm{OA}$ 材の $\delta_{f}$ も $400^{\circ} \mathrm{C}$ までは徐々に低下し， $400^{\circ} \mathrm{C}$ 以上で浪济一定かわずか に回復する。前述したように,このような $\mathrm{OA}$ 材にお ける $P_{\max }$ と $\delta_{f}$ の変化は, 加熱時効に起因した軟化に よるものである。それに対して，O材の機械的特性に ついては，乙の軟化に加え内部酸化層形成の影響が重 畳している. O 材の $P_{\max }$ と $\delta_{f}$ を $\mathrm{OA}$ 材のをれらで 規格化し，強度抒よび延性に及湾す雾囲気すなわち内 部酸化の影響のみを抽出したものを，図 9 に示す。 $P_{\mathrm{O}} / P_{\mathrm{OA}}$ あるいは $\delta_{\mathrm{O}} / \delta_{\mathrm{OA}}$ が1であるということは，内 部酸化の影響はなく, 機械的特性変化の要因は加熱時 効の影響(軟化)のみであることを意味している，同図 より，試験温度の上昇につれて $P_{\mathrm{O}} / P_{\mathrm{OA}}$ と $\delta_{0} / \delta_{\mathrm{OA}}$ がと

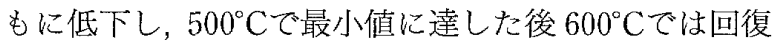
する傾向が認められる。

$3 \cdot 3$ 脆化あるいは乥の温度依存性の原因 上述 したように, $\mathrm{Cu}-\mathrm{Cr}-\mathrm{Zr}$ 合金に扔いては，内部酸化だ けでも機械的特性が大きく劣化すなわち脆化し, 脆化

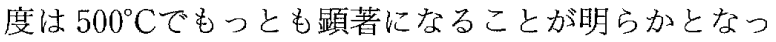
た。しかし，ての脆化あるいはそれが図80ような温 度依存性を示す原因については未だわかっていない。

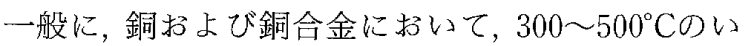
ずれかの温度にて延性が最小值を示し，それ以降では 再度延性が回復する現象が報告されている。この現象 は，中間温度脆性(6) (12) といわれる。この場合，破壊 形態は粒内ディンプルから粒界脆性破壊へと変化す る(6)。また，粗粒でひずみ速度が小さいほど脆性が現 れやすいことが知られている(10)(11)。この脆化の原因 としては, 不純物である硫黄 $(\mathrm{S})$ が重要な役割を担っ ていると考元られている(7)(8). 鈴木と伊藤(8) 素銅中の固溶 $\mathrm{S}$ 量を低下させると脆化感受性を示さ なくなることを観祭しているが，これは固溶 S 量の低

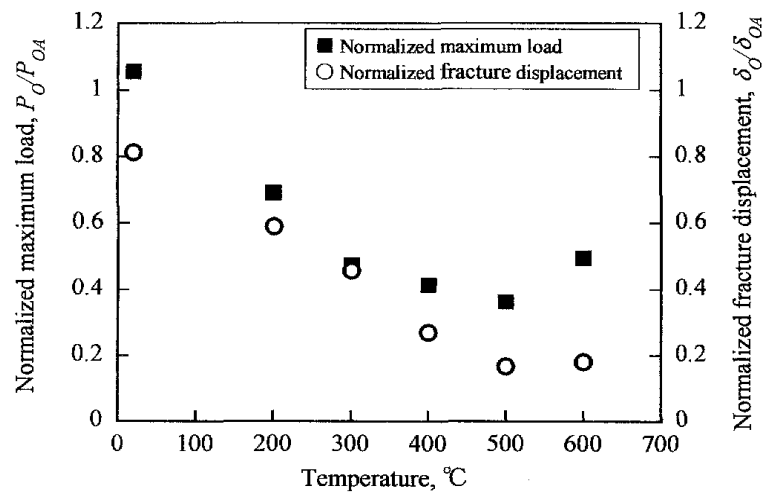

Fig. 9 Normalized maximum load and fracture displacement plotted as a function of testing temperature
下により動的再結晶温度が低下し，すべり帯による粒 界への応力集中がこの再結晶により緩和されるためだ

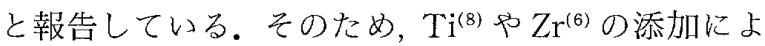
ってS を硫化物として固定すると，脆化現象が消失す る。また，菅野と下平(7)は，高温におけるSnの優先 的酸化 (内部酸化)やS の粒界偏析に上る粒界強度そ のものの低下が $\mathrm{Cu}-\mathrm{Sn}$ 合金に衫ける脆化の要因であ ると考元ている。さらに，彼らは， Ca, Y, Ce, $\mathrm{La}$ どの元素を添加すると，それらの脱硫效果によって高 温延性が改善すると報告している。

本 $\mathrm{Cu}^{-} \mathrm{Cr}-\mathrm{Zr}$ 合金も微量 (0.000 7 mass\%)であるが, 脆化が発現するとされる程度のSを含有している。 受入れまま状態では，このSは親和力の強い $\mathrm{Zr}$ と結 合し $\mathrm{ZrS}_{2}{ }^{(12)}$ として析出していると推測される。しか し, 内部酸化に上り粒界近傍化存在している $\mathrm{ZrS}_{2}$ が 式(1)のような反応によって選択的に酸化されて，そ の結果放出された Sが粒界㴜析したり粒内に固溶 したりする可能性がある.

$$
\mathrm{ZrS}_{2}+\mathrm{O}_{2} \rightarrow \mathrm{ZrO}_{2}+2 \mathrm{~S}
$$

そのため, $\mathrm{ZrS}_{2}, \mathrm{ZrO}_{2}$ 市よび $\mathrm{S}$ の粒界偏析などの検 出を目的として, 薄膜や抽出レプリカの透過電子頙微 鏡観察とオージェ電子分光法に上る粒界面分析を現在 実施しているが，量が極微量であるためか未だ検出さ れていない，一方で，酸化物 $(\mathrm{Zr}$ 酸化物, $\mathrm{Cr}$ 酸化物抒 よびその複合酸化物) そのものの物性あるいは機械的 特性が影響している可能性も否定できず，今後は上記 の観察および分析の精度をさらに高めていくととも に, 酸化物の詳細な分析も併せて実施していく予定で 亦る。

$3 \cdot 4$ 水素化に伴う機械的特性の変化 前節まで に，穴のメカニズムについては未だ解明できてはいな いものの, 内部酸化つまり $\mathrm{Zr}$ と $\mathrm{Cr}$ の選択的酸化に上 って, $\mathrm{Cu}-\mathrm{Cr}-\mathrm{Zr}$ 合金の機械的特性(強度㧍よび延性)

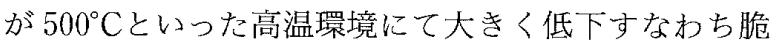
化することが明らかとなった，本節では，高温酸化䨌 囲気比曝された後引き続き高温還元雾囲気(高温水素 雾囲気) に曝される状況を模擬するため，O材に対し て高温高压水素ガス環境中にて水素チャージを行い, 機械的特性に及哚すその影響を SP 試験によって調查 した.

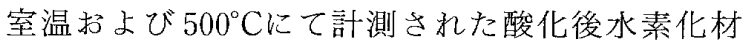
$(\mathrm{OH}$ 材) の荷重-荷重線上変位曲線を, $\mathrm{R}$ 材括よび $\mathrm{O}$ 材のものと併せて図 10 に示す. 図 10（a）の結果より, 内部酸化处理後に水素チャージを施すことによって室

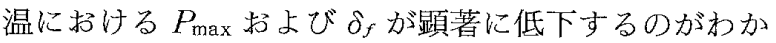
る。また, $500^{\circ} \mathrm{C}$ 极いても水素チャージによって 

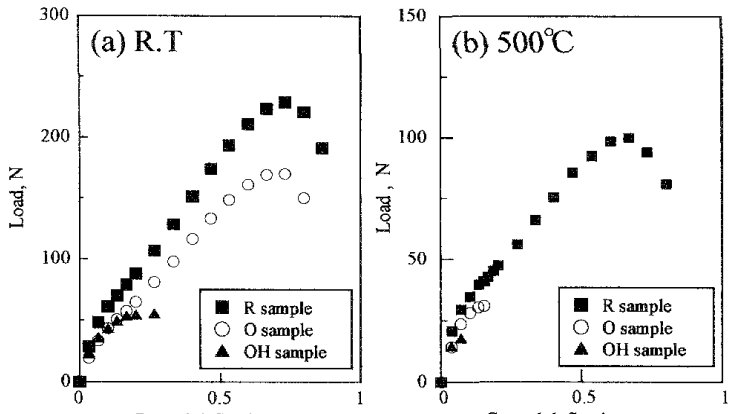

Central deflection, min

Fig. 10 Load $^{-}$central deflection curves measured on $\mathrm{R}$, $\mathrm{O}$ and $\mathrm{OH}$ samples at (a) R.T. and (b) $500^{\circ} \mathrm{C}$

$P_{\max }$ 打よび $\delta_{f}$ がさらに低下するが $[$ 図 10(b)]，内 部酸化のみでも大きく低下してしまうため，その滅少 量は室温に比べると決して多くはない。な报，受入れ まま材に対して水素チャージを行った試料について は, 脆化現象はまったく観察されなかった。また, 酸 化後水素化時効材 $(\mathrm{OHA}$ 材)の $\mathrm{SP}$ 試験上り, 水素于 ヤージによる機械的特性の劣化が, チャージ中の加熱 時効(軟化)により生じる現象ではなく,チャージされ た水素そのものが影響して現れる現象であることを確 認している。すなわち, $\mathrm{Cu}^{-} \mathrm{Cr}-\mathrm{Zr}$ 合金に扔いて水素 纪起因した脆化現象 (水素脆性)が発現するために注, あらかじめ内部酸化している必要があるということに なる。

$\mathrm{OH}$ 材の SP 試験後の試験片外観扔上び破面の SEM 像老，それぞれ図 11 および図 12 亿示す。図 11 より，マクロ的には室温㧍よび $500^{\circ} \mathrm{C}$ を脆性的な破 壞を呈しているのがわかる。破面観察の結果(図 12), 両温度とも粒界割机が生じていたが，破面の様相は両 温度で幾分異なっていた。室温では気泡が壊れたよう なディンプル状の凹凹が粒界面に形成されていたのに 対して, $500^{\circ} \mathrm{C}$ の破面は比較的滑らかであった。 $3 \cdot 1$ 節 で述べたように, 水素化処理後のミク口組織観察の結 果，酸化物の還元やその結果形成されるボイドなどは 確認できなかった。つまり， $\mathrm{Cu}-\mathrm{Cr}-\mathrm{Zr}$ 合金の水素脆 性の原因としては，これまで夕フピッチ銅や無酸素銅 にて報告されているものとは違うメカニズムが作用し ている可能性がある。今後は, $\mathrm{Zr}, \mathrm{Cr}$ 酸化物と水素と の反応性に関する詳細な検討を行うとともに，昇温脱 離分析や銀デコレーション法などによって合金中での 水素の存在状態を明らかにし, $\mathrm{Cu}^{-} \mathrm{Cr}-\mathrm{Zr}$ 合金に抒け る水素脆性のメカニズムを明らかにしていく予定であ る。

以上述べてきたように, 内部酸化さらにはその後の 水素チャージによって, 燃焼器用 $\mathrm{Cu}-\mathrm{Cr}-\mathrm{Zr}$ 合金の機
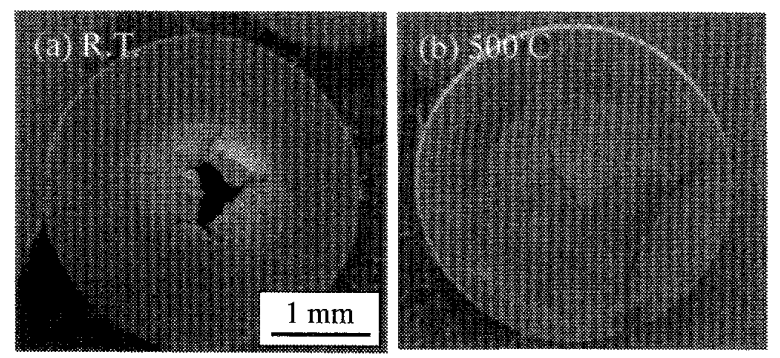

Fig. 11 SEM micrographs of fractured specimens of $\mathrm{OH}$ samples tested at (a) R.T. and (b) $500^{\circ} \mathrm{C}$
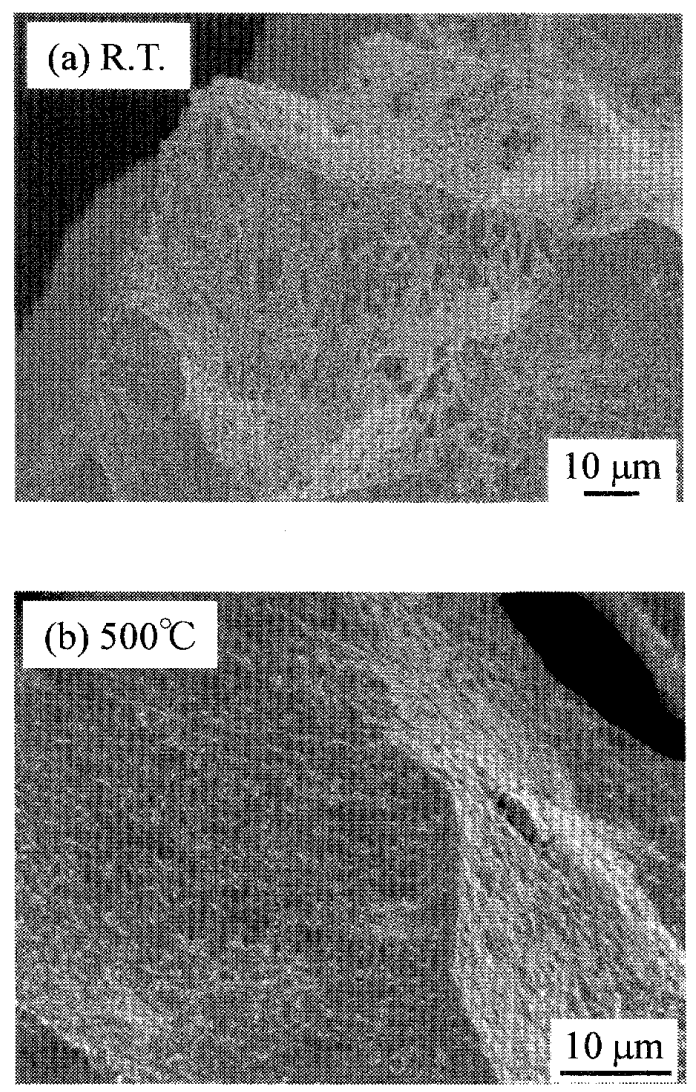

Fig. 12 SEM micrographs of fracture surfaces of $\mathrm{OH}$ samples fractured at (a) R.T. and (b) $500^{\circ} \mathrm{C}$

械的特性が大きく劣化すなわち脆化することがはじめ て明らかとなった。そ机らのメカニズムについては末 だ明らかにされてはいないが，この上うな知見が得ら れたことは，ロケット特に再使用型ロケット用燃焼器 の長寿命化の研究を行っていく上で極めて重要なこと である.今後は，前述したとおり，両脆化のメカニズ ムを明らか比すことはもちろんのこと，材料工学の 観点より脆化抑制のための指針を提示でき机ばと考兄 ている。 


\section{4. 結}

燃燒器用 $\mathrm{Cu}-\mathrm{Cr}-\mathrm{Zr}$ 合金に関する基礎的知見を得る ことを目的とし，その機械的特性に及ぼす内部酸化お よび水素テャージの影響を調査した。冷却溝の板厚は $1 \mathrm{~mm}$ 以下と極めて薄く通常の大型試験片を用いた標 準試験法を適用できないため，TEM ディスク形状の 微小試験片を用いたスモールパンチ(SP: Small Punch)試験により機械的特性を計測・評価した。得 られた知見をまとめて以下に示す。

（1）酸化試験によって形成された変質層(内部酸 化層)内では, 粒界で $\mathrm{Cr}$ と $\mathrm{r}$ が選択的に, 粒内では Cr 粒子が優先的に酸化される。また，水素チャージ による酸化物の還元や微小気泡の形成は今回確認でき なかった。

（2）内部酸化だけでも機械的特性(強度と延性)が 大さく劣化すなわち脆化する、試験温度が上昇すると 破壊形態は粒内ディンプルから粒界脆性破壊へと変化

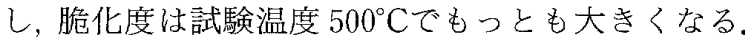
しかし，この脆化あるいはそれが温度依存性を示す原 因については未だわかていない。

（3）内部酸化処理だけではほとんど脆化現象が現 れない室温でも，内部酸化後に水素チャージを施すと 顕著に脆化する。なお，試験温度 $500^{\circ} \mathrm{C} に$ ないても水 素チャージによって脆化がさらに進行するが, 内部酸 化のみでも大きく低下してしまうため，その減少量は あまり多くはない.

\section{文献}

(1) Kamijoh, K. and Hirata, K., Fly the Roket (in Japanese), (1994), p. 105, Ohmsha.

(2) Mizuno, S., Hydrogen embrittlement and properties of copper, Unichemy Technical News (in Japanese), No.
$38(2004)$, p. 4.

(3) Ohkawa, M., Effects of Heating Time, Heating Temperature and Phosphorus Content on the Hydrogen Embrittlement of OFHC and Deoxidized Coppers by Oxidation and Reduction, Journal of Japan Copper and Brass Research, Vol. 012 (1973), pp. 175-185.

(4) Murphy, M., Anderson, R. E., Rousar, D. C. and Van Kleeck, J. A., Effect of oxygen/hydrogen combustionchamber environment on copper alloys, NASA Conference Publication 2437, (1986), pp. 497-501.

(5) Suzuki, H., Kawakatsu, I. and Kitano, H., Some properties of copper-high zirconium-high chromium alloys, Journal of the Japan Institute Metals, Vol.31, No. 4 (1967), pp. 342-346.

(6) Suzuki, H., Kanno, M. and Kitano, H., High-Temperature Embrittleness of $\mathrm{Cu}-\mathrm{Cr}$ Alloy, Journal of the Japan Institute Metals, Vol.34, No. 5 (1970), pp. 497501.

(7) Kanno, M. and Shimohira, N., Improvement of Hot Ductility of a Cu-4.4 mol\%Sn Alloy by Small Addition of Third Elements, Journal of the Japan Institute Metals, Vol. 51, No. 6 (1987), pp. 530-535.

(8) Suzuki, H. and Itoh, G., A Study of Intermediate Temperature Embrittlement in Pure Copper, Joumal of the Japan Institute Metals, Vol. 48, No. 10 (1984), pp. 1016-1021.

(9) Kanno, M., Ohsako, T., Shimohira, N. and Suzuki, H., Effects of a Small Amout of Additional Elements on Ductility of Tin-bronze at Elevated Temperatures, Journal of the Japan Institute Metals, Vol.50, No.9 (1986), pp. 782-787.

(10) Sibayanagi, T., Yoshimoto, A. and Hori, S., Relation between High Temperature Grain Boundary Failure and the Grain Boundary Character in $\mathrm{Cu}^{-}-10$ mass $\% \mathrm{Zn}$ Alloy, Journal of the Japan Institute Metals, Vol. 54, No. 1 (1990), pp. 9-16

(11) Muto, A., Goto, S., Kato, C. and Tagami, M., Effects of grain size and strain rate on high-temperature ductility of Cu-30 mass\% $\mathrm{Zn}$ alloy, Journal of the Association of Materials Engineering for Resources, Vol. 14, No. 1/ 2 (2001), pp. 35-42.

(12) Suzuki, H., Kanno, M. and Kitano, H., Increase of Recrystallization Rate of Pure Copper by the Trance Addition of Tí, Zr or V, Tetsu-to-Hagane, Vol. 70, No. 15 (1984), pp. 1977-1983. 